\title{
Gambaran protein urin pada pasien tuberkulosis paru dewasa di RSUP Prof. Dr. R. D. Kandou Manado
}

\author{
${ }^{1}$ Cecillia P. Tangkin \\ ${ }^{2}$ Arthur E. Mongan \\ ${ }^{2}$ Mayer F. Wowor
}

\author{
${ }^{1}$ Kandidat Skripsi Fakultas Kedokteran Universitas Sam Ratulangi Manado \\ ${ }^{2}$ Bagian Patologi Klinik Fakultas Kedokteran Universitas Sam Ratulangi Manado \\ Email: cecilliatangkin@gmail.com
}

\begin{abstract}
Tuberculosis (TB) is an infectious disease caused by Mycobacterium Tuberculosis that can affect almost any organ, especially lungs. Anti-tuberculosis drugs, such as rifampicin and streptomicin, are nephrotoxic or destructive to kidney cells. One of the markers of kidney function deficiency is increase protein excretion in urine or proteinuria. Proteinuria is one of the markers of decreased kidney function. This study was aimed to obtain the description of protein urine on pulmonary tuberculosis patients at Prof. Dr. R. D. Kandou Hospital Manado. This was an observational descriptive study on pulmonary tuberculosis patients conducted at Prof. Dr. R. D. Kandou Hospital Manado. Samples were obtained by using random urine specimen that met the predefined criteria. Most of the tesults of protein urinalysis of 30 patients were negative for protein. Some of the patients with positive results (proteinuria) had risk factors for comorbid disease that can intervened the protein urinalysis result. Conclusion: Protein urinalysis of 30 patients showed negative results in either in-patient or out-patient of pulmonary tuberculosis patients.
\end{abstract}

Keywords: pulmonary tuberculosis, urinalysis, proteinuria.

\begin{abstract}
Abstrak: Tuberkulosis (TB) adalah suatu penyakit infeksi yang disebabkan oleh bakteri Mycobacterium tuberculosis yang dapat menyerang berbagai organ, terutama paru-paru. Obat anti-tuberkulosis (OAT), seperti rifampisin dan streptomisin, dapat bersifat nefrotoksik atau destruktif terhadap sel-sel pada ginjal. Salah satu penanda adanya perburukan fungsi ginjal adalah ditemukan peningkatan ekskresi protein pada urin atau disebut proteniuria. Proteinuria merupakan penanda adanya perburukan fungsi ginjal. Penelitian ini bertujuan untuk mengetahui gambaran protein urin pada pasien tuberkulosis dewasa di RSUP Prof. Dr. R. D. Kandou Manado. Jenis penelitian ialah deskriptif observasional pada pasien tuberkulosis paru dewasa yang dilakukan di RSUP Prof. Dr. R. D. Kandou Manado. Sampel penelitian ialah sampel urin sewaktu dari semua pasien tuberkulosis paru yang memenuhi kriteria yang telah ditentukan. Berdasarkan urinalisis protein urin pada 30 pasien tuberkulosis paru, sebagian besar sampel menunjukkan hasil protein urin negatif. Beberapa pasien dengan hasil protein urin positif atau proteinuria memiliki faktor resiko penyakit penyerta yang dapat mengintervensi hasil urinalisis protein. Simpulan: dari hasil penelitian dapat disimpulkan bahwa hasil urinalisis protein pada 30 pasien tuberkulosis paru menunjukkan hasil protein urin negatif baik pada pasien rawat inap maupun rawat jalan.
\end{abstract}

Kata kunci: tuberkulosis paru, urinalisis, proteinuria.

Tuberkulosis adalah suatu penyakit infeksi yang disebabkan oleh bakteri Mycobacterium tuberculosis yang dapat menyerang berbagai organ, terutama paruparu. Tuberkulosis masih menjadi masalah kesehatan global. Tahun 2015, World 
Health Organization (WHO) memperkirakan ada sekitar 10,4 juta kasus baru di dunia dan 1,4 juta orang meninggal karena tuberkulosis. ${ }^{1}$ Prevalensi TB di Indonesia berdasarkan diagnosis sebesar $0,4 \%$ dari jumlah penduduk. Di Sulawesi utara, jumlah kasus tuberkulosis yang dilaporkan adalah 0,3\% dari jumlah penduduk dan di kota Manado pada tahun 2013 diperkirakan sekitar 1198 orang terdiagnosis menderita tuberkulosis. $^{2}$

Pengobatan kasus tuberkulosis merupakan salah satu strategi utama pengendalian tuberkulosis karena dapat memutuskan rantai penularan. Pengobatan tuberkulosis berupa pemberian obat antituberkulosis (OAT) dalam jangka waktu lama sekurang-kurangnya 6 bulan agar dapat mencegah perkembangan resistensi obat. OAT lini pertama yang biasa digunakan adalah Isoniazid, Rifampisin, Pirazinamid, Etambutol, dan Streptomisin. ${ }^{3}$

Rifampisin dan Streptomisin dapat menyebabkan gangguan pada fungsi ginjal atau bersifat nephrotoxic. Nephrotoxic memiliki sifat toksik atau destruktif terhadap sel-sel pada ginjal. ${ }^{4}$ Salah satu penanda dari adanya kerusakan pada ginjal adalah ditemukan peningkatan kandungan protein dalam urin atau dikenal dengan nama proteinuria. ${ }^{5}$

Urin normal sangat sedikit mengandung protein, peningkatan kandungan protein pada urin yang lebih dari $150 \mathrm{mg} / 24$ jam $(10-20 \mathrm{mg} / \mathrm{dL})$ menandakan adanya peningkatan kerja dari filtrasi glomerulus akibat kerusakan dari glomerular. ${ }^{5}$ Salah satu cara untuk mendeteksi protein dalam urin ialah dengan urinalisis. ${ }^{6}$ Urinalisis adalah analisis karakteristik fisik, kimia dan mikroskopik pada urin. ${ }^{7}$ Urinalisis telah dilakukan sejak 6000 tahun yang lalu dan merupakan pemeriksaan yang penting dalam menegakkan berbagai diagnosis klinis. ${ }^{8,9}$ Pemeriksaan ini masih tetap digunakan sampai sekarang karena murah, mudah dan cepat dilakukan sehingga direkomendasikan sebagai pemeriksaan awal dan rutin semua pasien sesuai indikasi. ${ }^{9}$

Penelitian ini bertujuan untuk mengetahui protein urin pada pasien tuberkulosis paru dewasa di RSUP Prof. Dr. R. D. Kandou Manado.

\section{METODE PENELITIAN}

Jensi penelitian ini ialah deskriptif dengan desain potong lintang. Penelitian ini dilaksanakan di Poliklinik paru dan instalasi rawat inap bagian penyakit dalam RSUP Prof. Dr. R. D. Kandou Manado selama bulan Oktober sampai November 2016. Sampel penelitian ialah sampel urin sewaktu dari semua pasien tuberkulosis paru dewasa dalam kurun waktu dan kriteria yang telah ditentukan dengan cara non-probability sampling jenis consecutive sampling.

\section{HASIL PENELITIAN DAN BAHASAN}

Berdasarkan hasil penelitian, didapatkan jumlah sampel sebesar 30 pasien diantaranya terdiri dari 6 pasien rawat inap dan 24 rawat jalan.

Pada penelitian dapat dilihat bahwa kelompok usia 36-45 tahun merupakan kelompok usia terbanyak yang menderita tuberkulosis paru. Hasil penelitian ini serupa dengan hasil penelitian yang dilakukan oleh Rukmini et $a l^{10}$ yang mendapatkan jumlah penderita tuberkulosis paru terbanyak pada kelompok usia 35 - 54 tahun (26,7\%). Penelitian ini sedikit berbeda dari data Kementrian Kesehatan RI tahun 2015 yang menunjukkan bahwa tuberkulosis paling banyak ditemukan pada kelompok usia 25-34 tahun (20,7\%) diikuti kelompok usia 45-54 tahun $(19,6 \%)$ dan pada kelompok usia 35-44 tahun $(19,2 \%){ }^{11}$

Tabel 1. Distribusi pasien TB paru menurut usia

\begin{tabular}{ccc}
\hline Usia & Jumlah & $\boldsymbol{\%}$ \\
\hline 18-25 Tahun & 4 & $13,3 \%$ \\
26-35 Tahun & 4 & $13,3 \%$ \\
36-45 Tahun & 8 & $26,7 \%$ \\
46-55 Tahun & 6 & $20,0 \%$ \\
56-65 Tahun & 6 & $20,0 \%$ \\
66-75 Tahun & 2 & $6,7 \%$ \\
Total & 30 & $100,0 \%$ \\
\hline
\end{tabular}


Menurut data dari WHO, tuberkulosis dapat menyerang setiap kelompok usia. Namun, angka kejadian tertinggi ditemukan pada kelompok usia produktif secara ekonomi (15-59 tahun). ${ }^{2}$ Berdasarkan hasil ini, prevalensi tuberkulosis paru meningkat pada usia produktif.

Pada penelitian ini dari 30 sampel pasien tuberkulosis paru yang diteliti, terdapat 20 orang $(66,7 \%)$ laki-laki dan 10 orang $(33,3 \%)$ perempuan. Hasil penelitian ini sesuai dengan hasil penelitian yang dilakukan oleh Rukmini et $a l^{10}$ yang menunjukkan bahwa tuberkulosis paru lebih banyak terjadi pada laki-laki $(61,3 \%)$. Selain itu, hasil penelitian ini juga sesuai dengan data dari Kementrian Kesehatan RI tahun 2015 yang menunjukkan bahwa prevalensi tuberkulosis paru pada laki-laki lebih tinggi yaitu sebesar $0,4 \%$ dibandingkan pada perempuan yang sebesar $0,3 \%{ }^{11}$ Berdasarkan hal tersebut, prevalensi tuberkulosis paru lebih tinggi pada laki-laki.

Tabel 2. Distribusi pasien TB paru menurut jenis kelamin

\begin{tabular}{ccc}
\hline Jenis Kelamin & Jumlah & $\mathbf{\%}$ \\
\hline Laki-laki & 20 & $66,7 \%$ \\
Perempuan & 10 & $33,3 \%$ \\
Total & 30 & $100,0 \%$ \\
\hline
\end{tabular}

Pada penelitian terlihat pasien yang terdiagnosis tuberkulosis paru didapatkan bahwa penyakit penyerta terbanyak ialah pasien dengan gangguan ginjal dengan jumlah pasien yaitu 6 orang $(20,0 \%)$ ( Tabel 3). Hal ini mendukung teori yang menyatakan bahwa pada pasien dengan penyakit ginjal terjadi disfungsi sistem imun berupa depressed cell-mediated immunity (CMI) sehingga pasien penyakit ginjal memiliki resiko $10-15$ kali lebih besar untuk mendapatkan infeksi, termasuk infeksi TB. $^{12}$

Pada penelitian dapat dilihat bahwa jenis kasus terbanyak pada tuberkulosis paru adalah kasus baru sebanyak 13 orang (43,3\%). Hal ini sesuai dengan hasil penelitian Susilayanti ${ }^{13}$ yang menunjukkan bahwa jumlah penderita TB paru BTA positif sebagian besar berupa kasus baru 1017 orang $(91,7 \%)$. Hasil penelitian ini juga serupa dengan penelitian Zalitha ${ }^{14}$ yang menunjukkan bahwa proporsi terbesar penderita TB paru pada kasus baru sebesar 97,5\%. Berdasarkan hal ini, kasus baru merupakan jenis kasus terbanyak pada tuberkulosis paru (Tabel 4).

Tabel 3. Distribusi pasien TB paru menurut penyakit penyerta

\begin{tabular}{lcc}
\hline Penyakit Penyerta & Jumlah & \% \\
\hline Hipertensi & 4 & $13,3 \%$ \\
Asam urat & 5 & $16,7 \%$ \\
Diabetes melitus & 5 & $16,7 \%$ \\
Gangguan ginjal & 6 & $20,0 \%$ \\
\hline
\end{tabular}

Tabel 4. Distribusi pasien TB paru menurut jenis kasus

\begin{tabular}{lccc}
\hline \multirow{2}{*}{ Jenis kasus } & $\begin{array}{c}\text { Rawat } \\
\text { Inap }\end{array}$ & $\begin{array}{c}\text { Rawat } \\
\text { Jalan }\end{array}$ & Total \\
\cline { 2 - 4 } & Jumlah & Jumlah & Jumlah \\
\hline Baru & 1 & 12 & 13 \\
Gagal terapi & 0 & 1 & 1 \\
Putus Obat & 3 & 5 & 8 \\
Relaps & 2 & 6 & 8 \\
$\quad$ Total & 6 & 24 & 30 \\
\hline
\end{tabular}

Pada penelitian diperoleh hasil jenis OAT yang paling banyak dikonsumsi adalah OAT kategori 1 yaitu sebanyak 24 orang $(80,0 \%)$ (Tabel 5). Terapi OAT kategori 1 ini diberikan kepada pasien baru yang terkonfirmasi bakteriologis atau terdiagnosis klinis atau pasien tuberkulosis ekstra paru. Berdasarkan pemaparan sebelumnya, kasus baru merupakan jenis kasus yang paling banyak ditemukan pada pasien tuberkulosis paru. Oleh karena itu, penggunaan OAT kategori 1 yang paling banyak ditemukan pada penelitian ini.

Pada Tabel 6 didapatkan hasil protein urin pada pasien tuberkulosis paru. Sebagian besar menunjukkan hasil negatif $(53,3 \%)$. Sedangkan hasil trace terdapat pada 3 orang $(10 \%)$ dan hasil positif atau proteinuria pada 11 orang $(36,7 \%)$. Hasil protein positif dapat menandakan adanya suatu perburukan pada fungsi ginjal. 
Namun, ada beberapa kondisi yang mnyebabkan proteinuria tanpa adanya kerusakan ginjal atau disebut proteinuria transien. Proteinuria transien disebabkan oleh beberapa kondisi sepeti aktivitas fisik berat, dehidrasi, stress emosional, demam dan terpapar dingin. Proteinuria transien bersifat sementara, reversible dan dapat kembali normal setelah beristirahat. Sedangkan, proteinuria dengan kerusakan ginjal disebut juga dengan protinuria persisten. ${ }^{15,16}$

Tabel 5. Distribusi pasien TB paru jenis OAT

\begin{tabular}{cccc}
\hline \multirow{2}{*}{ Jenis OAT } & $\begin{array}{c}\text { Rawat } \\
\text { Inap }\end{array}$ & $\begin{array}{c}\text { Rawat } \\
\text { Jalan }\end{array}$ & Total \\
\cline { 2 - 4 } & Jumlah & Jumlah & Jumlah \\
\hline Kategori 1 & 4 & 20 & 24 \\
Kategori 2 & 2 & 4 & 6 \\
Total & 6 & 24 & 30 \\
\hline
\end{tabular}

Tabel 6. Distribusi hasil pemeriksaan urinalisis pada pasien TB paru

\begin{tabular}{lcc}
\hline \multicolumn{1}{c}{ Nilai } & Jumlah & \% \\
\hline Negatif & 16 & $53,3 \%$ \\
Trace & 3 & $10,0 \%$ \\
Positif & 11 & $36,7 \%$ \\
$\quad$ Total & 30 & $100,0 \%$ \\
\hline
\end{tabular}

Tabel 7. Distribusi hasil pemeriksaan urinalisis protein pada pasien TB paru berdasarkan jenis penyakit penyerta

\begin{tabular}{lccc}
\hline \multicolumn{1}{c}{$\begin{array}{c}\text { Penyakit } \\
\text { penyerta }\end{array}$} & \multicolumn{3}{c}{ Nilai } \\
\cline { 2 - 4 } Diabetes & Negatif & Trace & Positif \\
\hline $\begin{array}{l}\text { melitus } \\
\text { Hipertensi }\end{array}$ & 2 & 0 & 3 \\
$\begin{array}{l}\text { Asam urat } \\
\text { Gangguan }\end{array}$ & 0 & 0 & 1 \\
ginjal & 0 & 2 & 3 \\
\hline
\end{tabular}

Peningkatan kandungan protein urin dapat juga disebabkan karena adanya pengaruh dari penyakit penyerta seperti diabetes melitus, hipertensi, asam urat dan gangguan pada ginjal. Pada Tabel 7, penyakit penyerta pada pasien tuberkulosis paru yang paling banyak mengalami proteinuria atau hasil dipstik protein positif adalah penyakit ginjal $(13,3 \%)$, diikuti asam urat $(10,0 \%)$, diabetes melitus $(10,0 \%)$ dan yang terakhir hipertensi $(3,3 \%)$. Proteinuria merupakan manifestasi klinis paling umum pada penyakit ginjal. Proteinuria tidak hanya menunjukkan tanda kerusakan ginjal, tetapi juga memberikan gambaran penyakit ginjal kronis. ${ }^{17}$

Proteinuria juga terjadi pada penderita asam urat atau hyperuricemia. Hal ini sesuai dengan hasil penelitian yang menunjukkan bahwa dari 5 orang yang memiliki penyakit penyerta asam urat, 2 orang memiliki hasil protein urin trace dan 3 orang memiliki hasil protein urin positif. Hyperuricemia merupakan salah satu penanda dari disfungsi renal yang progresif. Mekanisme terjadinya mungkin karena aktivasi dari Renin Angiotensin System (RAS), mediator penting pada penyakit ginjal progresif, yang terjadi akibat efek hemodinamik yang meningkatkan tekanan glomerular dan efek fibrogenik pada ginjal dan vascular cells. ${ }^{18}$ Selain itu, hipertensi dan diabetes melitus merupakan salah satu faktor resiko terjadinya kerusakan pada ginjal yang ditandai dengan peningkatan kandungan protein dalam urin atau disebut proteinuria. Teori ini sesuai dengan hasil penelitian yang menunjukkan bahwa dari 5 orang yang mengalami diabetes melitus, 3 orang memiliki hasil positif. Namun, sedikit berbeda dari hasil penelitian yang menunjukkan bahwa dari 4 pasien yang mengalami hipertensi, hanya 1 orang yang memiliki nilai protein urin positif sedangkan 3 orang lainnya memiliki nilai negatif.

Hipertensi merupakan salah satu faktor utama yang memicu terjadinya mikroalbuminuria dan ini merupakan penanda awal dari adanya penurunan fungsi ginjal yang progresif. Peningkatan ekskresi dari albumin terjadi akibat perubahan hemodinamik pada ginjal akibat peningkatan tekanan sistemik pada glomeruli, perubahan permeabilitas filtrasi glomerulus atau insufisiensi reabsorsi tubulus dan kerusakan struktural pada 
glomeruli dan arteriol. Pasien dengan Hipertensi yang lama dan tidak terkontrol menyebabkan tingginya tekanan intraglomerular dan menyebabkan kerusakan fungsi filtrasi glomerulus. Kerusakan glomerulus menyebabkan peningkatan ekskresi abnormal protein ke dalam urin. ${ }^{19}$

Selain itu, pada diabetes melitus menahun yang tidak terkontrol dapat memicu terjadinya nefropati diabetik yang ditandai dengan penurunan LFG (Laju Filtrasi Glomerulus), hipertensi yang perjalanannya progresif serta mikroalbuminuria. Tingginya kadar gula dalam darah akan membuat struktur ginjal berubah (disfungsi endotelial) sehingga fungsinya pun terganggu, protein (albumin) dapat melewati glomerulus akibat kerusakan glomerulus. Apabila tidak segera ditangani, lama kelamaan jumlah protein yang dikeluarkan kedalam urin akan semakin meningkat secara progresif dan proteinuria akan persisten, kerusakan glomerulus berlanjut, hingga akhirnya terjadi penurunan fungsi ginjal hingga kerusakan ginjal atau gagal ginjal. ${ }^{20,21}$

Pada Tabel 8, ditemukan bahwa hasil protein urin positif atau proteinuria terdapat pada pasien TB paru yang mengonsumsi OAT kategori 1 dan OAT kategori 2.

Tabel 8. Distribusi hasil pemeriksaan urinalisis protein pada pasien TB paru berdasarkan jenis OAT

\begin{tabular}{lcc}
\hline \multirow{2}{*}{ Nilai } & Kategori & Kategori \\
& $\mathbf{1}$ & $\mathbf{2}$ \\
\cline { 2 - 3 } & Jumlah & Jumlah \\
\hline Negatif & 15 & 4 \\
Trace & 3 & 0 \\
Positif & 6 & 2 \\
\hline
\end{tabular}

Seperti yang telah dipaparkan sebelumnya, hasil protein positif dapat dipengaruhi oleh adanya penyakit penyerta. Dengan melihat hasil protein urin pada pasien TB paru tanpa penyakit penyerta (Tabel 9). Pada Tabel 9, hasil protein urin positif hanya terdapat pada penderita TB paru tanpa penyakit penyerta yang mengonsumsi OAT kategori 1.

Tabel 9. Distribusi hasil pemeriksaan urinalisis protein pada pasin TB paru tanpa penyakit penyerta berdasarkan jenis OAT

\begin{tabular}{lcc}
\hline \multirow{2}{*}{ Nilai } & $\begin{array}{c}\text { Kategori } \\
\mathbf{1}\end{array}$ & $\begin{array}{c}\text { Kategori } \\
\mathbf{2}\end{array}$ \\
\cline { 2 - 3 } & Jumlah & Jumlah \\
\hline Negatif & 9 & 3 \\
Trace & 1 & 0 \\
Positif & 3 & 0 \\
\hline
\end{tabular}

OAT kategori 1 terdiri dari isoniazid, pirazinamid, rifampisin dan etambutol. Sedangkan OAT kategori 2 terdiri dari isoniazid, pirazinamid, rifampisin, etambutol dan streptomisin. ${ }^{3}$ Penelitian ini lebih fokus terhadap efek samping dari rifampisin dan streptomisin yang bersifat nephrotoxic sehingga dapat terjadi gangguan fungsi dari ginjal dan menyebabkan peningkatan kandungan protein dalam urin atau proteinuria., ${ }^{4,5}$

Rifampisin adalah salah satu obat anti tuberkulosis yang paling sering digunakan. Walaupun jarang $(0,1 \%$ dari pasien tuberkulosis), rifampisin dapat bersifat nephtotoxic dan menyebabkan gagal ginjal akut. Insiden rifampisin nephrotoxic bervariasi sekitar $1,8 \%$ - $16 \%$ dari semua kasus gagal ginjal akut. Efek samping nefrotoksik ini biasanya muncul pada pasien yang mengonsumsi rifampisin secara intermiten. Pasien yang pernah putus obat kemudian melanjutkan pengobatan kembali setelah interval waktu tertentu lebih beresiko mengalami efek samping rifampisin nefrotoksik. Interval waktu berkisar antara 5 bulan - 11 tahun dapat menyebabkan gagal ginjal dan manifestasi awal terjadi pada $10-20$ hari setelah pengobatan ulang. Mekanisme reaksi ini berhubungan dengan kemampuan rifampisin dalam memproduksi respon imun (anti-rifampicin antibodies) yang menyebabkan dekstrusi pada sel tubular sehingga terjadi penurunan fungsi ginjal. $^{4,22,23}$

Selain rifampisin, streptomisin juga dapat bersifat nefrotoksik. Streptomisin 
merupakan golongan aminoglikosida pertama yang muncul sejak tahun 1944. Streptomisin memiliki efek nefrotoksik yang paling rendah jika dibandingkan dengan obat golongan aminoglikosida lainnya. Mekanisme nefrotoksis terjadi setelah aminoglikosida masuk kedalam korteks ginjal dan tubulus proksimal, melalui proses endositosis dan sequestration, aminoglikosida berikatan dengan lisosom dan membentuk myeloid bodies/secondary lysosome. Kemudian membran lisosom pecah dan melepaskan asam hidrolases yang mengakibatkan kematian sel dan menyebabkan penurunan fungsi dari ginal. Penurunan fungsi ginjal ini dapat ditandai dengan ditemukannya proteinuria. ${ }^{4,24}$

Pada Tabel 10, dari 16 orang pasien TB paru tanpa penyakit penyerta, hasil protein urin positif paling banyak ditemukan pada pasien dengan lama pengobatan 3-4 bulan. Menurut teori, lama pengobatan dapat berpengaruh terhadap nefrotoksisitas pengobatan. Pada rifampisin beberapa kasus dilaporakan nefrotoksisitas terjadi setelah $>2$ bulan terapi, meskipun reaksi awal juga dapat muncul dalam 13 hari pengobatan. Sedangkan pada streptomisin, resiko nefrotoksik meningkat pada lama pengobatan $>10$ hari. $^{4,25}$ Semakin meningkat resiko nefrotoksikitas, maka akan terjadi peningkatan kandungan protein urin akibat penurunan fungsi ginjal. Berdasarkan hal tersebut, hasil protein positif dapat dipengaruhi oleh lamanya pengobatan.

Tabel 10. Distribusi hasil pemeriksaan urinalisis protein pada pasien TB paru tanpa penyakit penyerta berdasarkan lama pengobatan

\begin{tabular}{cccc}
\hline Penyakit & \multicolumn{3}{c}{ Nilai } \\
\cline { 2 - 4 } penyerta & Negatif & Trace & Positif \\
\hline$<1$ bulan & 4 & 0 & 1 \\
$1-2$ bulan & 2 & 1 & 1 \\
$3-4$ bulan & 0 & 0 & 2 \\
$5-6$ bulan & 1 & 0 & 0 \\
$>6$ bulan & 3 & 0 & 0 \\
\hline
\end{tabular}

Penjelasan tentang hubungan tuberkulosis paru dan pemeriksaan protein urin masih kurang lazim dilaporkan atau diteliti. Kelebihan pada penelitian ini adalah pengambilan sampel tidak bersifat invasif, cepat dan biaya penelitian terjangkau.

\section{SIMPULAN}

Berdasarkan hasil penelitian yang dilakukan di RSUP Prof. Dr. R. D. Kandou Manado dapat disimpulkan bahwa sebagian besar pasien TB paru memiliki hasil protein urin negatif. Beberapa pasien dengan hasil positif (proteinuria) memiliki beberapa faktor risiko yang dapat mengintervensi hasil urinalisis. Sehingga diperlukan evaluasi dan pemeriksaan protein urin lebih lanjut.

\section{SARAN}

Perlu penerapan metode analitik sehingga bisa mengetahui hubungan sebab akibat antara kedua variabel tuberkulosis paru dan protein urin. Jumlah sampel penelitian perlu diperbanyak dan perlu informasi lebih lengkap tentang data pasien dan subjek penelitian untuk menghindari terjadinya bias dalam penelitian

\section{DAFTAR PUSTAKA}

1. WHO, Global Tuberculosis Report 2016.

2. Kementerian Kesehatan RI, Badan Penelitian dan Pengembangan Kesehatan. Riset kesehatan dasar. 2013.

3. Kementerian Kesehatan RI, Direktorat Jendral Pengendalian Penyakit dan Penyehatan Lingkungan. Pedoman Nasional Pengendalian Tuberkulosis. Jakarta. 2014.

4. Singh NP, Ganguli A, Prakash A. Drug Induced Kidney Disease. J Assoc Physicians India. 2003;51:970-8.

5. Oni MO, Oguntibeju OO. Clinical and diagnostic importance of proteinuria: A review. Afr J Biotechnol. 2008;7(18):3166-72.

6. Simerville JA, Maxted WC, Pahira JJ. Urinalysis: A comprehensive review. Am Fam Physician. 2005;71(6):115362.

7. Abirami K, Tiwan SC. Urinalysis in 
clinical practice. J Indian Acad Clin Med. 2001;2:40-5.

8. International Society of Nephrology. Urinalysis in western culture: A brief history. 27 Desember 2006 [cited 2016 Sep 13]. Available at: https://www.ncbi.nlm.nih.gov/pubme d/17191081/

9. Roxe DM. Urinalysis. In:Walker HK, Hall WD, Hurst JW, editors. Clinical methods: The history, physical, and laboratory examinations. 3rd edition. Boston: Butterworths; 1990. Chapter 191. p.868-71.

10. Rukmini, Chatarin UW. Faktor-faktor yang berpengaruh terhadap kejadian TB paru di Indonesia (Analisis data riset kesehatan dasar tahun 2010). Buletin Penelitian Sistem Kesehatan. 2010;14(4):320-31.

11. Kementrian Kesehatan RI. Pusat Data dan Informasi. Data dan Informasi Tahun 2015 Profil Kesehatan Indonesia. Jakarta. 2015.

12. Mimi N, Medregoniu D, Oltean M, Golli A. Tuberculosis and Chronic Renal Failure: Therapy Patterns. Current Health Science Journal. 2011;37(2):106-8.

13. Susilayanti E, Medison I, Erkadius. Profil Penderita Penyakit Tuberkulosis Paru BTA Positif yang ditemukan di BP4 Lubuk Alung periode Januari 2012 - Desember 2012. Jurnal Kesehatan Andalas. 2014;3(2):151-5.

14. Zalitha S. Profil penderita penyakit tuberkulisis paru di RSU Siti Hajar Medan (skripsi). Medan: FK USU;2011.

15. McPherson RA, Ben-Ezra J. Basic Examination of urine. In: McPherson RA, Pincus MR. Henry's Clinical Diagnosis and Management by Laboratory Methods. $22^{\text {nd }}$
ed.China:Elsevier;2011. p.445-53.

16. Carroll MF, Temte JL. Proteinuria in Adults: A Diagnostic Approach. Am Fam Physician. 2000;62(6):1333-40.

17. Venkat KK. Proteinuria and Microalbuminuria in Adults: Significance, Evaluation, and Treatment. Southern Med Journal. 2004;97(10):969-976.

18. Kang D, Nakagawa T, Feng $L$, Watanabe S. A Role for Uric Acid in the Progression of Renal Disease. J Am Soc Nephrol. 2002;13:2888-97.

19. Rodicio JL, Campo C, Ruilope LM. Microalbuminuria in essential hypertension. Kidney International. 1998;54(68):51-54.

20. Satchell SC, Tooke JE. What is the Mechanism of Microalbuminuria in Diabetes: a Role for Glomerular Endothelium. Diabetologia 2008;51(5):714-725.

21. Batuman V. Diabetic Nephropathy. Medscape. 2016 September $30^{\text {th }}$ [cited 2016 November $29^{\text {th }}$ ]. Available at : http://emedicine.medscape.com/articl e/238946-overview/

22. Rekha VV, T Santha, Jawahar MS. Rifampicin-induced Renal Toxicity During Retreatment of Patient with Pulmonary Tuberculosis. J Assoc Physicians India. 2005;53:811-3.

23. Babe A, Seaworth B, Patil N. Rifampicininduced nephrotoxicity in a tuberculosis patiet. J Clinc Tuber Microbiol. 2005;4:13-5.

24. Sandhi JS, Sehgal A, Gupta O, Singh A. Aminoglycoside Nephrotoxicity Revisited. J Indian Acad Clin Med. 2007;8(4):331-3.

25. Naughton CA. Drug-Induced Nephrotoxicity. Am Fam Physician. 2008;78(6):743-750. 